\title{
Overcoming Small to Medium Business Failure through Leadership Strategies
}

\author{
Gregory R. Jackson \\ Walden University, Minneapolis, USA \\ Email: gjacksonr@yahoo.com
}

How to cite this paper: Jackson, G. R. (2021). Overcoming Small to Medium Business Failure through Leadership Strategies. Open Journal of Business and Management, 9, 353-384.

https://doi.org/10.4236/ojbm.2021.91019

Received: December 27, 2020

Accepted: January 26, 2021

Published: January 29, 2021

Copyright (c) 2021 by author(s) and Scientific Research Publishing Inc. This work is licensed under the Creative Commons Attribution International License (CC BY 4.0).

http://creativecommons.org/licenses/by/4.0/

(c) (i) Open Access

\begin{abstract}
Grounded in the transformational leadership theory, the purpose of this qualitative multiple case study was to explore leadership strategies that have been successful for small to medium urban enterprise (SME) owners in urban areas to sustain their business for more than 5 years. The participants were $3 \mathrm{SME}$ owners in urban areas of southeast Georgia, who have been in business for more than 5 years. Data were collected through semistructured interviews and an analysis of researcher notes along with a review of each SME owner's response to obtain information about successful leadership strategies. A thematic analysis process was used to analyze data; 3 themes emerged: focus on employees through training to improve performance, maintain the business by developing strategies for efficient operations and relate to the industry in which the business is operating. The result of the study indicated key recommendations for SME owners including implementing employee performance training and developing strategic planning. The implications for positive social change have the potential for community enhancement opportunities through sustained employment and the leveraging of goods and services financed by SMEs increased and sustained presence.
\end{abstract}

\section{Keywords}

Business Capital, Business Practices, Business Strategies, Ethical Leadership, Succession Planning

\section{Introduction and Background}

Georgia small businesses employed 1.6 million people or $43.2 \%$ of the private workforce, and firms with fewer than 100 employees have the largest share of small business employment (SBA, Office of Advocacy, 2018). Small businesses play a crucial economic role worldwide and are the drivers of economic growth 
and development (Blankson, Cowan, \& Darley, 2017). Small businesses create wealth, economic growth, and development in the world (Blankson et al., 2017). However, $50 \%$ of small businesses fail within 5 years of startup (SBA, Office of Advocacy, 2016). Additionally, small business leaders struggle to profit and compete over a startup period (Wang, Hawkins, \& Berman, 2014).

According to Dalpiaz, Tracey, and Phillips (2017), small-to-medium (SME) leaders lack the ability to develop and implement succession plan strategies. Leaders should construct succession planning strategies as part of their organizational framework (Dalpiaz et al., 2017). Existing literature reflect various perspectives on leadership performance and sustainability of small businesses. SME Leadership is relevant in the success of small businesses in urban areas.

This qualitative multiple case study was to explore leadership strategies that have been successful for SME owners in urban areas to sustain their business more than 5 years. The participants were 3 SME owners in urban areas of Southeast Georgia, who have been in business for more than 5 years. Data were collected through semistructured interviews and an analysis of researcher notes along with a review of each SME owner's responses to obtain information about successful leadership strategies. A thematic analysis process was used to analyze data; 3 themes emerged: focus on employees through training to improve performance, maintain the business by developing strategies for efficient operations and relate to the industry in which the business is operating.

\section{Purpose Statement}

The purpose of this qualitative multiple case study was to explore leadership strategies that have been successful for SME owners in urban areas to sustain their business beyond 5 years. The research population consisted of SME owners in southeast Georgia who have been in business beyond 5 years. The findings of this study serve as ideal business models identifying leadership strategies required for SME success. SME owners using successful leadership strategies discovered in this study may extend SMEs' business beyond 5 years. Social change may occur through the availability of jobs created from SMEs in business beyond 5 years and increased tax revenue in urban areas due to SMEs staying in business to provide funds for poverty alleviation and the expansion and improvement of city facilities such as parks and schools.

\section{Research Question}

The Central Research Question guiding this study was what leadership strategies do SME owners in urban areas use to sustain their business beyond 5 years? Data derived from semistructured interviews, SME website information, and interview notes.

\section{Assumptions, Limitations, and Delimitations}

Assumptions are beliefs related to the study a researcher believes to be accurate 
or valid (Valentin, 2014). Marshall and Rossman (2016) indicated assumptions are facts considered correct but unverified. I considered three assumptions associated with this study. The initial assumption is that the study participants have familiarity with strategic leadership and whether the participants in the study possess the strategic leadership background suitable for SME success. The research question is necessary to gather information regarding leadership strategies to benefit SMEs. The second assumption is that using a qualitative case study is appropriate to explore leadership strategies for SMEs to sustain business beyond 5 years. The final assumption is that the participants possess information regarding the research questions, and participants in the study did not allow personal bias to impact the interview session's responses.

Limitations are possible weaknesses of the study beyond the control of the researcher (Morgado, Meireles, Neves, Amaral, \& Ferreira, 2018) as well as vulnerabilities in research usually derived from the study of one region geographically, small sample sizes, or limited data availability (Dowling, Brown, Legg, \& Beacom, 2018). Limitations are factors in the design or methodology of a study that affect the application or interpretation of the results of the study (Merriam, 2014). Limitations affect the study's validity based on the findings determined by the manner the design and methodology are implemented (Merriam, 2014). Successful SME's may limit the research scope because of the exclusion of unsuccessful SME owners. A multiple case study of the selected SMEs from Georgia may not yield enough data to answer the research questions and may not represent the population of different SME owners in the Unites States.

The SME sample size and urban location of southeast Georgia, present limitations that do not reflect other geographical locations. Lewis (2015) defined delimitations as characteristics setting boundaries of the researcher that limit the study's scope. This study focuses on SMEs owners in urban areas who have sustained business beyond 5 years; therefore, larger enterprises and SMEs who have not sustained their business beyond 5 years were not within the study's boundaries. The scope of this study is confined to SMEs in southeast Georgia. Successful SMEs in other urban areas outside of the southeast area are not in this study's scope.

\section{Significance of the Study}

\subsection{Contribution to Business Practice}

This study's findings could be of value to SME owners in urban areas because the results can be useful for formulating a narrative regarding SME success through purposeful leadership strategies. SME owners may utilize the narrative to improve leadership strategies, enhance employee morale, increase productivity, and to achieve and maintain profit gains. Using the results of the study, SME owners in urban areas may develop greater strategic and leadership skills to remain sustainable while increasing market shares, talent, stakeholder benefits, and lower operational cost and employee turnover (Banker, Mashruwala, \& Tripathy, 2014). 
Furthermore, by using or adapting the study's findings, the pool of talented business owners might improve their economic prosperity (Banker et al., 2014).

\subsection{Implementation for Social Change}

Using the results of this study, reductions in SME failures may increase job opportunities in the urban environment and decrease neighborhood crime. The implications for positive social change include the potential for enhancing community standards through sustained employment and the leveraging of goods and services financed by increased SMEs sustained presence. In addition, the socioeconomic landscape of urban communities may improve because of a SME's success.

\section{A Review of the Academic Literature}

\subsection{Transformational Leadership}

A transformational leader's role is to motivate, create a vision, and influence the attitudes of followers (Pradhan \& Pradhan, 2015). Transformational leadership is an approach where the concentration of power is in leaders who see their mission as transforming other people. Leaders who use this leadership style intend to change and transform people (Northouse, 2015). Frieder, Wang, and Oh (2018) defined transformational leadership as a social process where members of a group or organization influence the understanding of internal and external events, the choice of goals or desired outcomes, the organization of work activities, and the individual motivation and abilities. Leaders use management style to transform others during change; as such, leaders with this style increase creativity and innovation (Pardo-del-Val, Fuentes, \& Dobón, 2012). Pardo-del-Val et al. posited that leaders influence resistance to change and increase change results. Leaders who use the transformational leadership style allow members outside the leadership circle influence in the decision-making process to facilitate and improve the success of change (Pardo-del-Val et al., 2012). According to Shurbagi (2014), transformational leadership style is a central feature of organizational performance, while job satisfaction and organizational commitment parallel hypothetically and empirically to organizational effectiveness.

Transforming leadership became transformational leadership in the mid-1970s (Burns, 1978). Burns (1978) introduced the idea of transforming leadership through his research on political leaders. Transformational leaders set a moral example to benefit the team, organization, and community and change an organizational culture (Burns, 1978). In 1985, Bass (1985) expanded the research to consider the psychological mechanisms that trigger transformational leadership, ways to measure it, and how transformational leaders affect follower motivation and performance. Bass also suggested that followers feel trust, admiration, loyalty, and respect for transformational leaders because transformational leaders provide followers with an inspiring mission, vision, and identity. 


\subsection{Entrepreneurship}

Entrepreneurship is a business owner's opportunistic pursuit to provide future products, processes, and services, leveraging personal strengths to mobilize business capabilities. Entrepreneurs create innovation opportunities in products, services, processes, and business models with entrepreneurship education as a key beneficiary of entrepreneurial design thinking (Groth, Esposito, \& Tse, 2015). Hundera (2014) emphasized the importance of developing an integrated conceptual framework in the field of entrepreneurship. The diversification of entrepreneurship and SMEs' specialization reflects the various theoretical perspectives (Rauch, Doorn, \& Hulsink, 2014).

Entrepreneurship is associated with individual characteristics and attitudes toward business, while other researchers relate entrepreneurship to cultural conditioning (Hulbert, Gilmore, \& Carson, 2015). Sahut and Peris-Ortiz (2014) identified how SMEs operate in an ecosystem suitable for entrepreneurship that necessitates commitment and close collaboration between employees. Sahut and Peris-Ortiz highlighted a psychological progression toward entrepreneurship by family and institutions, indicating the collaborative shift in entrepreneurial advancement. Entrepreneurially minded people start small firms because they recognize opportunities larger firms overlook (Hulbert et al., 2015). Entrepreneurs with entrepreneurship education approach the world with fresh ideas to create desired futures and adopt cognitive acts to reduce the uncertainty associated with ambiguous situations (Garbuio, Lovallo, Dong, Lin, \& Tschang, 2018).

Leadership is relevant to entrepreneurship (Balven, Fenters, Siegel, \& Waldman, 2018). Entrepreneurs must understand SME dynamics and learn to develop appropriate strategies that suit their circumstances to manage SMEs effectively (Bamiatzi \& Kirchmaier, 2014). Balven et al. (2018) categorized leadership as a micro process at the relational level, and it captures the interplay between the faculty member and other individual technological transfers. Entrepreneurs who participate in coordinated entrepreneurship programs develop core competencies to help them develop the capacity to identify potential opportunities to gain a competitive advantage (Chang, Liu, \& Chiang, 2014).

\section{Small to Medium Enterprises}

The SME sector has been described as an essential factor in sustaining the economic growth and development of most economies due to adjustments to environmental changes and technological orientation (Pooe, Mafini, \& Loury-Okoumba, 2015). Although 50\% of small businesses fail within 5 years of startup (SBA, Office of Advocacy, 2016), small businesses create wealth, economic growth, and development in the world (Blankson et al., 2017). David and Rowe (2016) described SMEs as companies characterized by criteria that do not exceed certain quantitative limits, varying by location. Small business owners are owners of small businesses (Weber, Geneste, \& Connell, 2015), with most SMEs employing fewer than 500 employees (SBA, Office of Advocacy, 2017). Small firm owners 
were responsible for providing 61.8\% of new jobs from 1993 to 2016 (SBA, Office of Advocacy, 2016).

Pooe, Mafini, and Loury-Okoumba (2015) conceptualized SME performance in terms of its ability to increase or improve its overall outcomes in cash flow, profitability, customer satisfaction, sales growth, and employee growth. Small businesses create reward systems to nurture employees (Pooe et al., 2015). Small business owners are essential to the U.S.'s growth and health (Jeger, Sarlija, \& Bilandzic, 2016) and strengthen local and national economies (Neagu, 2016). Many minority small entrepreneurs fail to optimize the benefits resulting from implementing strategic management theories (Popa \& Miricescu, 2015). Pooe et al. (2015) posited that because there is little separation between ownership and control of operational activities in SMEs, SMEs' success relates to their owners' abilities to make the best use of their managerial skills experience expertise.

\section{Research Method and Design}

This qualitative multiple case study's objective was to explore leadership strategies that have been successful for SME owners in urban areas to sustain their business beyond 5 years. I selected a qualitative research methodology to collect data through inquiries from interviews, participant notes, and participant reflections to obtain existing information about leadership strategies to help SME owners to sustain operations beyond 5 years.

\subsection{Research Design}

I selected a multiple case study design. A case study design entails methodological flexibility through the integration of diverse paradigms, study designs, and methods and exploring a contemporary phenomenon in depth within a real-life context (Yin, 2018). A case study design is viewed as an adaptable approach when analyzing societal and developmental disciplines (Gottfert, 2015). Dasgupta (2015) explained that researchers use a case study research strategy to gather information from individuals and groups to describe an understanding of an occurrence. De Massis and Kotlar (2014) explained that researchers use case study design to provide a comprehensive investigation that allows for reviewing multiple perspectives provided in the case study design. A multiple case study is used to collect data from more than one source, e.g., two organizations, three sports teams, or ten departments (Yin, 2018). I selected a multiple case study research design for this study because I relied on diverse paradigms, study designs of understanding SME owners' experiences in a real-life context that have sustained their business beyond 5 years, from multiple data sources for evidence to study a phenomenon.

\subsection{Population and Sampling}

The research participant sample consisted of 10 SME owners in urban areas located in Southeast Georgia, who have been in business beyond 5 years. The pop- 
ulation included small business owner from southeast Georgia. The industries of the population included the trucking business, family services, graphic design, property management, software companies, health care, and security companies. The sample size included participants from the e-trucking company, family services, and a security company. The intent in selecting the desired sample was to identify those SMEs who have applied leadership strategies resulting in the sustained success of the business for more than 5 years. The criteria for selecting the SME owners are SME is in an urban area, SME owner is in a leadership position, SME owner has had the business for more than 5 years, and SME owner has a willingness to share successful experiences and leadership strategies.

The selection of research participants is critical to data outcomes, and equally critical is the sampling technique in selecting participants (Gelling, 2015; Marshall \& Rossman, 2016). Participants of this study were determined via the purposeful sampling method. Researchers use purposeful sampling to gather data when participants are in their natural environment and comfortable during the interview (Duan, Bhaumik, Palinkas, \& Hoagwood, 2015). Purposeful sampling is one of the pioneer techniques for qualitative research (Marshall \& Rossman, 2016). The purposeful sampling technique facilitates researcher confidence when obtaining valuable information from knowledgeable participants relating to a phenomenon. The phenomenon will become more precise and understandable only when data saturation is achieved (Duan et al., 2015; Morse, 2015a). Purposeful sampling entails selecting participants who will provide rich, practical knowledge of the occurrence (Marshall \& Rossman, 2016). Williams and Needham (2016) described purposeful sampling as a qualitative sampling technique used to choose participants who possess the knowledge, experiences, and characteristics of the study subject.

Researchers consider the amount of information needed to serve the purpose and credibility of a study when selecting a sample size (Duan et al., 2015). The sample size of ten successful SMEs in urban areas who sustained their business beyond 5 years is adequate for this study. The sampling of 10 to twelve participants in a case study is suitable to amass enough data necessary to understand an occurrence's context. At least two to three participants are the smallest acceptable sample size in multiple case studies (Yin, 2018). An essential element of multiple case study research is to ensure data saturation (Yin, 2018).

The SMEs owners selected were asked to participate in semistructured interviews to reach data saturation. Data saturation is a systematic guideline to ensure researchers have collected sufficient data, understood the meaning participants give to their statements, coded all the information appropriately, and analyzed themes faithfully (Fusch, Fusch, \& Ness, 2017). Data saturation is the evidence of rigor in qualitative research and occurs when no new themes emerge from the data (Fusch et al., 2017). Moser and Korstjens (2018) posited that data saturation is when no new data or information is needed. Moser and Korstjens also noted that one way to ensure data saturation is to ensure that the selected 
participants possess the successful experience and knowledge relevant to the research topic. Researchers can cease the interviews and justify the sample chosen when data saturation is achieved (Morse, 2015a). I continued the semistructured interview with open-ended questions until data saturation was attained where no additional was required for the study. Based on the purposeful sampling method and ensuring data saturation, I selected the SMEs owners to accomplish this research study's objectives.

\subsection{Data Collection Instruments}

As the researcher and primary data collection instrument in this qualitative multiple case study, I collected data via semistructured interviews. Qualitative researchers serve as primary instruments when conducting interviews (Yin, 2018). In qualitative research, the interview process is a conventional method used to collect descriptive rich text data, and participants' share their ideas through responding to semistructured interview questions, playing an active role in the data collection process (Yin, 2018). Wilson (2014) indicated researchers recommend semistructured interviews in qualitative research because participants are meaningfully involved and have more room for expressing their perceptions and experiences. Participants were informed of the interview protocol and provided a copy of the interview questions. The interview protocol entailed an overview of the study, the introduction of the research question, a description of data collection procedures, and data analysis. Using an interview protocol helps increase the reliability of case study research (Yin, 2018).

Yin (2018) indicated a case study should encompass at least two evidentiary sources for data collection. Case study designs require researchers to collect data from two or more sources (Galdas, 2017). I used member checking to ensure the appropriate interpretation of the data and the data's accuracy. Yin (2018) described member checking as summarizing information obtained from the participants, and researchers help to avoid bias by including member checking in their research design. Member checking enables participants to review the researchers' description of the participant's experiences (Galdas, 2017). Birt, Scott, Cavers, Campbell, and Walter (2016) recommended researchers to use member checking techniques to ensure the accuracy of the interpretation of the information from the interview. Galdas (2017) noted that researchers had recommended member checking to ensure the reliability and validity of the data collected from the semistructured interviews.

\subsection{Data Collection Technique}

Data collection consisted of information gathered from the participants (Yin, 2018). Morse (2015a) recommended that researchers start their interview process by selecting a small sample (initial analysis sample), collect and analyze data to find themes, and then conduct more interviews until no new themes or data are available. I requested participants' agreement via email to obtain their 
permission to participate in the study. I worked with participants who responded to the email invitation and agreed to participate in the study to schedule a time to conduct the semistructured interview via phone call. Interviews should be conducted in an environment that would encourage participants' openness to express their experiences (Yin, 2018). Due to COVID-19 face to face restrictions, I conducted the semistructured interview via phone call at a mutually agreed time. Data collected occurred via the recorded interviews from participants. The semistructured interview was recorded and transcribed using Otter.ai application. An interview is crucial to engaging participants in the audio-recording process and establishing trust with participants (Morse, 2015a). The semistructured interviews and audio-recordings allowed me, as the researcher, to gain an understanding of the leadership strategies SME owners used to sustain business beyond 5 years.

Advantages of using the semistructured interview in data collection are the interview process that allows the researcher to use open-ended inquiries to extract participants' perspectives and experiences regarding an occurrence (Marshall \& Rossman, 2016). Semistructured interviews allow replication and in-depth questions with more detailed information, and participants may feel more comfortable answering questions with a well-designed protocol (Bond et al., 2014). To avoid the disadvantages of the semistructured interview, I performed member checking to obtain an accurate interpretation and data collection accuracy. Researchers avoid bias by including member checking in their research design (Galdas, 2017). Researchers achieve rigor, reliability, generalizability, and avoid bias by including member checking in their research design (Galdas, 2017; Morse, 2015b). Member checking renders participants the opportunity to review the researcher's description of the participant's experiences (Galdas, 2017).

Participant information must be kept confidential and identities should not appear in the study (Wallace \& Sheldon, 2015). Participant protection, confidentiality, and general welfare shall be protected (Wallace \& Sheldon, 2015). To ensure participants' ethical protection and for the protection of participant privacy, I used alphanumeric identification codes for their identities. I used SME-1, SME-2, and SME-3 instead of the names of participants and their organizations. I did not report the names of the participants or organizations.

\section{Data Analysis}

Data analysis is when the researcher interprets the collected data and forms an understanding of the concepts discovered during the investigation (Graue, 2015). Researchers analyze data to develop meaning and follow a consistent set of propositions to create meaning from participants' experiences (Graue, 2015). Various techniques exist for conducting the analysis process that includes the deconstruction and reconstruction of data collected to identify codes and themes to facilitate interpretation and understanding of the participants' views and experiences (Yin, 2018). A qualitative study's data analysis process involves four 
steps: data collection, data reduction, data display, and conclusions (Yin, 2018). Yin (2018) indicated 4-stage data analysis process includes decontextualization, recontextualization, categorization, and compilation. In this study, I used the data analysis approach by Elo et al. (2014) to prepare the data for analysis, coding, and organizing the data to identify themes and patterns and interpret and report the results. Using the stages of analysis described by Elo et al., I performed a content analysis of the data collected via the research participants recorded semistructured interviews.

I prepared the data for analysis, beginning with the collection process. Data collection was through semistructured interviews. In qualitative research, the interview process is a conventional method used to collect descriptive rich text data, and participants' share their experiences through responding to semistructured interview questions, playing an active role in the data collection process (Yin, 2018). A researcher using an interview protocol helps increase the reliability of case study research (Yin, 2018).

The information obtained during the interview process was audio-recorded and transcribed using Otter.ai application. Advantages of using the semistructured interview in data collection are the interview process that provides structure and allows the researcher to use open-ended inquiries to extract participants' perspectives and experiences regarding a phenomenon (Marshall \& Rossman, 2016). According to Seidman (2015), researchers commonly record interviews and later transcribe the data because these actions protect the interview's full content and facilitate categorization and analysis of the data. In qualitative studies, researchers generate data from narrative materials transcribed verbatim from the in-depth interview (Chang et al., 2014).

The organizing and coding of the data were used to identify themes and patterns. I organized the data by starting with transcribing the interviews into MS Word $^{\odot}$. NVivo ${ }^{\mathrm{TM}} 12$ software, the latest version of $\mathrm{NVivo}^{\mathrm{TM}}$, was used to organize and code the data collected. $\mathrm{NVivo}^{\mathrm{TM}}$ is a commonly used qualitative data analysis tool (Jackson, Paulus, \& Woolf, 2018). Researchers use NVivo ${ }^{\mathrm{TM}}$ to store, organize, and manage qualitative data (Jackson et al., 2018). I used NVi$\mathrm{vo}^{\mathrm{TM}} 12$ for my study because of its ease of use and to import documents directly via the word processing software (Miles, Huberman, \& Saldaña, 2014). I imported the transcription from MS Word ${ }^{\odot}$ into NVivo ${ }^{\mathrm{TM}} 12$ and began coding the transcribed data. Coding identifies keywords grouped to find phrases or common themes reoccurring in the data and aids in identifying repeated themes and words (Miles et al., 2014).

Data interpretation and reporting of the results were performed via the coded themes. Researchers apply coding stripes, making it easy for the researcher to see the codes and connect the emerging themes (Jackson et al., 2018). Data content analysis performance occurred to correlate the key themes emerging from the research data with the literature review, research question, and the study's conceptual framework (Graue, 2015). Participant information must be kept confi- 
dential, and identities should not appear in the study (Graue, 2015). Participant protection, confidentiality, and general welfare shall be protected (Wallace \& Sheldon, 2015).

Researchers recommend triangulation to analyze data in multiple case study research (Yin, 2018). Triangulation is described as the cross-examining of data from different sources to achieve a more accurate and valid estimate of a specific construct (Carter, Bryant-Lukosius, DiCenso, Blythe, \& Neville, 2014; Yin, 2018). Triangulation involves using various data collection methods that ensure richness, reliability, and trustworthiness of the study (Fusch et al., 2017). Data can be triangulated via data triangulation, investigator triangulation, theory triangulation, and methodological triangulation (Carter et al., 2014). I performed methodological triangulation to triangulate the interview data with SME participant responses, SME website information, and interview notes to assure validity during the data analysis. I applied methodological triangulation to analyze and identify data about leadership strategies that have been successful for SME owners in urban areas in Georgia to sustain their business beyond 5 years. Researchers use methodological triangulation to interpret and understand the data, according to Carter et al. (2014).

All recorded and transcribed data were maintained and documented on completed transcripts. Study participants received a 1-2-page summary of the results of this study upon completion of data analysis. I identified short phrases from the complete transcripts to link regularities and patterns in the overall data (Miles et al., 2014).

\section{Reliability and Validity}

Researchers in a qualitative study assesses the findings' reliability and validity using appropriate designs and methods (Leung, 2015). Reliability and validity are related to the accuracy and precision of research and intended to make qualitative research rigorous (Morse, 2015b; Stanton, 2016). In a multiple case study, the use of several relevant data sources is a vital approach to achieve conclusive findings and ensure the study's reliability and validity (Yin, 2018). Criteria used to determine qualitative research rigor include dependability, credibility, confirmability, and transferability (Houghton, Casey, Shaw, \& Murphy, 2013). Birt et al. (2016) stated that member checking is appropriate in the case study for credibility, reliability, validity, and transferability of data collected and the results' trustworthiness. The higher the levels of validity, credibility, and reliability, the more trustworthy a study is future researchers can use the findings as a basis for their related studies (Yin, 2018).

Reliability refers to the consistency within analytical procedures employed in deriving the study's findings (Shayestefar \& Abedi, 2017). The use of multiple data collection sources or evidence enhances case study reliability (Ridder, 2017). Elo et al. (2014) noted that reliability is analogous to dependability and transferability. In this study, I used the interview protocol to ensure study relia- 
bility. Participants were informed of the interview protocol. Yin (2018) maintained that the interview protocol helps increase the reliability of case study research.

Triangulation is a means for confirming the reliability of the data collected during the interviews by comparing the data with other sources (Yin, 2018). Carter et al. (2014) described four triangulation types as investigator triangulation, data triangulation, theory triangulation and methodological triangulation. Researchers perform investigator triangulation when gathering and analyzing data (Carter et al., 2014). According to Burau and Andersen (2014), researchers use several data sources and sampling methods in data triangulation. Burau and Andersen (2014) noted that researchers employ theory triangulation to explore various theoretical frameworks and interpret a phenomenon. Researchers apply methodological triangulation to implement more than one technique to ensure the data is valid and reliable (Fusch et al., 2017). I applied methodological triangulation to help to ensure reliability.

Qualitative researchers conduct valid analysis by incorporating credibility, confirmability, and transferability in their studies (Amankwaa, 2016). The accuracy and the truthfulness of the data demonstrate the research study's validity (Fusch et al., 2017). Validity refers to the research data's integrity and how accurately the findings reflect the research data (Shayestefar \& Abedi, 2017). According to Leung (2015), validity in qualitative research refers to the suitability of the tools, processes, and data. I employed methodological triangulation to help to ensure validity. In the data analysis processed from the semistructured interviews, SME documentation, and notes taken during the interview, I disassembled, compartmentalized, and reassembled the data to establish themes and draw inferences.

Credibility is applied toward the research design, instrumentation, and data (Ravitch \& Carl, 2016). Posner (2016) explained the origins of the Leadership Practices Inventory (LPI) as empirical instrument to measure The Five Practices of Exemplary Leadership framework, a major transformational leadership model. The essential psychometric properties of the LPI are both the LPI normative database, with nearly 2.8 million respondents, as well as pertinent findings of several hundred studies conducted worldwide by scholars utilizing the LPI in their research. Issues of both reliability and validity are with the conclusion that the LPI is quite robust and applicable across a variety of settings and populations.

Results of the scores from the LPI show construct and predict validity, with the underlying factor being structure sustained across a variety of studies and settings (Posner, 2016). Posner noted the internal reliabilities for the five leadership practice scales are very good and are consistently strong across a variety of sample populations and situations. Posner concluded the Leadership Practices Inventory has sound psychometric properties and the findings are relatively consistent between constituent groups, genders, ethnicity, cultural backgrounds, 
and national boundaries, as well as across various contextual characteristics (e.g., positions and industry).

\section{Findings}

The research question for this qualitative multiple case study was what leadership strategies do SME owners in urban areas use to sustain their business beyond 5 years? To answer the research question, data occurred through semistructured interviews with SME owners. Data collection consisted of information gathered from the participants. Each participant's semistructured interview lasted about 60 minutes. I used SME-1, SME-2, and SME-3 instead of the names of participants to ensure confidentiality. I used methodological triangulation by reviewing participant websites and cross-checking participant responses to ensure data was dependable and credible. Transformational leadership theory was the conceptual framework for this study. A transformational leader's role is to motivate, create a vision, and influence the attitudes of followers (Pradhan \& Pradhan, 2015). Transformational leadership is a social process where members of a group or organization influence the understanding of internal and external events, the choice of goals or desired outcomes, the organization of work activities, and the individual motivation and abilities (Frieder et al., 2018).

Based on the SME interviews' data analysis, three themes were identified that participant SME owners focused on as leadership strategies to sustain their business. The three themes were derived from the completion of coding, methodological triangulation, and member checking SME participant response. The themes that emanated from data analysis were the following:

- Theme 1: Focus on employees.

- Theme 2: Maintain the business.

- Theme 3: Relate to industry.

Each theme is described in the sections below. The themes, focus on employees, maintain the business, and relate to the industry are relevant because of the applicability, relatability, and frequency of occurrence analyzed from participants. The themes are also construed as ingredients for strategic planning and success, and they align as a focus with the research question and conceptual framework. The results indicate that the use of all themes or a combination of each theme may result in SME success. The data analysis also revealed participant SME owners highlighted the themes during the operation of their respective businesses. The three themes were identified to shape the successful leadership strategies and are recommended for SME owners in urban areas to concert their focus on for SME success. The results are inconsistent: however, as SME owners in urban areas are not absolved from considering or applying additional strategies or practices relating to leadership, entrepreneurship, leadership skills, and strategic planning. Further, the results indicate the application of additional considerations pertaining to leadership, entrepreneurship, leadership skills, and strategic planning also serve as successful leadership strategies. Still, they do not 
guarantee SME total success.

\subsection{Theme 1: Focus on Employees}

All study participants referenced employees as a critical aspect and focus as a leadership strategy. Each participant SME owner confirmed Ployhart, Nyberg, Reilly, \& Maltarich, (2014)'s research that small businesses depend on human capital resources to operate from a different perspective of human capital resources such as economics, strategy, human resources, and psychology to develop an incorporated and holistic framework for success. Ployhart et al. noted that human capital is a useful asset for business success, and human capital must have the required skills to be productive. Managing employee job motivation is an important element of an organization's human capital strategy (Campbell, Im, \& Jisu, 2014). The quality of human capital is essential for SMEs' owners because SME owners depend more on human capital than other capitals (Ployhart et al., 2014).

Study participants agreed employee function is reliant on the success of their business. SME-1 articulated, "We are working with people: we want the people as employees that we work with to be at their best." SME-1 continued that, "leaders must be positive and have positive employees that believe in your vision." When questioned regarding leadership strategies to manage employees, SME-2 noted that leaders should be more of a coach than a boss when it comes to being in charge of employees. SME-2 asserted the importance of treating employees as if leaders and employees are like a team, highlighting the importance of leadership to present themselves more like a coach or like a team leader and see the value of building relationships with people/employees. I reviewed SME-2's website during methodological triangulation to verify the interview response and found as part of the mission statement, and their goal is to support their staff and their clients in operating securely and efficiently, in making informed, educated decisions and in reducing overall risks. SME-3 stated, "owners know what employees need from the organization. They know what is going on." SME-3 provided the example that in urban areas, employees look toward being paid, learning more about the organization, personal development, and becoming interested in a career. SME-2 and SME-3 recommend when confronting or dealing with employees to stay away from being an autocratic leader. SME-3 shared "the goal of a leader is to motivate and lead to maximize employee performance and production to maximize income." SME-1 shared "employees can be there just for the paycheck" but believes that is not a formula to be successful in any business.

Tse and Chiu (2014) confirmed the idea that transformational leadership style is crucial to employee performance and the organization's organizational culture. Leadership skills are both fundamental and necessary for any organization to succeed (Bruyere, 2015). SME-1 posited that it is helpful to develop a group or core team of employees to help work in the vision direction. The participants 
agreed they had to inspire and motivate their employees during their journey to improve their business. The transfer of knowledge from an expert to a mentee or employee improves learning and performance (Prince, Burns, Lu, \& Winsor, 2015). Knowledge transfer takes place in urban SME through communication between leaders, organizations, and employees (Prince et al., 2015).

Research findings indicated that engaged employees were more productive than disengaged employees (Bedarkar \& Pandita, 2014). According to Campbell and Goritz (2014), organizational culture influences employee engagement. SME-2 shared "the biggest value that I've brought to my company that allows me to sustain this is to be able to have great and good alliances to build relationships with the people that I work with." If employees are not engaged and do not associate with organizational culture, high employee turnover is the result (Campbell \& Goritz, 2014). Employee disengagement is associated with higher costs and reduced productivity (Choi, Tran, \& Park, 2015).

The study results indicated the importance of employees and the impact employees play in the SME owner's success. As an effective strategy for SME success in urban areas, it is imperative to focus on employees. This finding confirms the research by Choi et al. (2015) that business leaders understand the skills and strategies leaders use to engage employees, leading to improved employee performance and organizational competitiveness. Operational efficiency is the company's ability to combine the right people, technologies, materials, and processes to optimize business performance (Godha \& Jain, 2015). Bedarkar and Pandita (2014) noted the benefits of understanding the skills and strategies needed to facilitate engagement result in improved productivity, increased profit, and an engaged workforce.

A recurring theme from the participants' responses was the reliance on their employees. SME-1 admitted that a reliance on the workers provided comfort and overwhelming trust. All the participants conveyed that they used their leadership skills to motivate employees to get better production and output, resulting in their SME success. Sahin, Cubuk, and Uslu (2014) noted that transformational leadership styles positively affect employees and organizational performance. Factors such as pay, leadership, environment, self-efficacy, reward, and recognition can all increase or decrease employee job performance (Lin, Yu, \& Yi, 2014). As transformational leaders, SME owners provide employees with a clear sense of guidance and aspiration, building employee commitment and trust that results in the organization's overall success (Bayram \& Dinç, 2015).

\subsection{Theme 2: Maintain the Business}

Study participants referenced the importance of understanding business as an additional critical aspect and a leadership strategy. Researchers have indicated the relation of business and strategy as instrumental ingredients to SME success. Entrepreneurial experience is essential to ensure business sustainability (Jayawarna, Jones, \& Macpherson, 2014). Small business owners grow their business 
by being strategic (McDowell, Gibson, Aaron, Harris, \& Lester, 2014). Business success depends on the decision-making ability and the development and implementation of strategies by business leaders (Myškova \& Doupalova, 2015).

SME owners may benefit by incorporating strategies to build their business platforms (Choi et al., 2015). SME-1 shared a story relating to the research of Choi et al. (2015) incorporating strategies to build business platforms. SME-1 stated, "the business struggled because there was no existing strategy to move the business forward. I had to come up with a strategy to incorporate my vision and my mission to get my business to the next level. Without a strategy, the business would have failed." SME-2 stated, "above all things, you have to be strategic and plan to keep your business going. It, maintaining the business, must be done. It has to be done no matter what".

Business strategies are a set of vision, mission, values, practices, approaches and technologies that confer a firm a competitive advantage on a market (Pattinson, 2016). Small business owners may acquire strategies that lead to an increased business performance in the long term (Taneja, Pryor, \& Hayek, 2016). SME-3 stated, "I was forced to come with a darn plan. My wife was the one who mentioned that there was a need to. I had to do better." SME-3 added, "All I knew as was I had to maintain my company or else. I had to do what was necessary to maintain my trucks, keep maintenance up, and keep everything going." Neis, Pereira, and Maccari (2017) posited that strategic planning is the way small firm owners balance the external environment and their business's internal capabilities. Business owners who design firm strategies search for profitable products, carefully monitor costs, avoid intense price wars, and witness growth, even in hostile markets (Bamiatzi \& Kirchmaier, 2014). Leaders and SME owners with comprehensive business plans accomplish business sustainability (Oncioiu, 2014).

Business leaders understand the skills and strategies leaders use to engage employees, leading to improved employee performance and organizational competitiveness (Choi et al., 2015). The benefits of understanding the skills and strategies needed to facilitate engagement result in improved productivity increased profit, and an engaged workforce (Bedarkar \& Pandita, 2014). SME-1 and SME-3 noted that using strategies has allowed their business to grow every year since they have been in business. SME-1 commented, "having strategies also allowed me to stay competitive in the business that I'm in.” Relating to business, SME-2 stated "owners should recognize there are different compartments of the business. There's the client focus and then there's the staff focus." SME-2 added, "Owners are to compartmentalize all of the important aspects of the company and then identify all of the resources that are needed for each compartment. The last thing is to apply all of the necessary tools and resources to accommodate the needs of each compartment." SME-3 commented "focus on being efficient. Manage the staff. Manage the maintenance and manage the vision for building the business". 
A key maxim of transformational leadership is organizational and individual goal alignment. It is imperative that leadership training contain orientation to the practice and reinforce an organization's mission (Morrison, Greenshaw, \& Pigg, 2019). Mom, van Neerijnen, Reinmoeller, and Verwaal (2015) asserted that leaders who align goals execute effective business practices and gain employee trust, leading to cohesion within the organization. SME-1 supported the research by Mom et al. (2015) stating "I had to go against my administrative team and everybody else and help them to understand that we're going to do this, whether you believe in it or not. And I actually had to really go head-to-head with my own staff. And today, they are so loyal and so appreciative that I did that." I reviewed SME-1's website during methodological triangulation to validate how they maintain their business, noting how, through a business they provide preventive strategies through its range of family-based programs. They also learned to negotiate and develop solutions by communicating, compromising and using diplomacy, which resulted in appropriate resolutions to problems. SME-1 noted, "my website is our way of offering potential clients an introduction to our services and what we do for our community." SME-2 shared, "put yourself in a position to have the same level of success. Based on the assessment of other companies, have a little bit of a blueprint to follow." Similarly, SME-3 shared, "put yourself in position to be successful. It is always good practice to be in the right position at the right time." SME-3 added, having mentors, business mentors that basically lay a formula out. Now they might have their own specific formula, but it might take a little bit of their information, a little bit of a couple of other guys or other companies. Then formulate your own formula.

SME-3 also commented, "it is all determined by the market and it is also determined by a lot of business being seasonal. Seasonal rotation understanding is important".

The study results indicated the importance of maintaining the business as an effective strategy by participants. A recurring theme by the participants equally was by all means necessary to "Maintain the Business". The posturing to maintain the business parallels the research by Qureshi, Aziz, and Mian (2017) that entrepreneurship and entrepreneurial perspectives allow the business leaders to be flexible and adopt the best strategies for the unique needs of the business. SME-2 stated, "try to make an emotional connection with the clients. Connect to what to their system is, making them feel safe. Engage them to connect to their emotions. SME-2 added, "listen to the customer and understand what they want, not necessarily what I offer".

Kornberger (2017) noted that a business plan is essential to clarify the business mission and values, set clear goals, define resources, understand the actors in the market, and to remain competitive. Sustainable strategic planning is a cycle process that consists of defining the firm's mission and assessing the firm's competitive position (Kornberger, 2017). In each respective participant perspective, they agreed it is imperative to maintain the business, no matter the chal- 
lenges or obstacles encountered, especially during the first few years of start-up. The determination and diligence displayed by maintaining the business posture, along with implementing strategies to support the vision and mission, is certain to yield positive sustainable and maintainable results.

\subsection{Theme 3: Relate to Industry}

Study participants identified the importance of having the business be relatable to the industry SME owners are operating within, regardless of the product, the service or the medium that either will be delivered. Small businesses operate in a rapidly dynamic and active market and are dependent on the environment in which they operate (Mustafa, 2015). As such, relationships exist between both SME and the environment where they exist. Entrepreneurs and other small business owners use their networks, experience, and better judgment to obtain collaborative support to identify market risk and capitalize on the rapidly changing technology to benefit their businesses (Kim \& Vonortas, 2014). Entrepreneurs discover unsatisfied needs in the community and create an organization to profit or for a philanthropic goal (Pontikes \& Barnett, 2017).

SMEs struggle to overcome internal and external factors that hinder their growth (Lofti, Nayebzadeh, \& Debnavi, 2014). To defeat this, small business owners may acquire strategies that lead to an increased business performance in the long term (Taneja et al., 2016). SME-1 commented, "the key to survive in business is to learn the ins and outs of business and what we were trying to do. The small office space and minimal staff was a challenge we had to overcome." SME-2 stated, "I decided to run my security business different from other security businesses in the area to set ourselves apart. I learned this from watching and speaking with others in the industry." SME-2 added, "it was so hard to change in the beginning, we noticed we were feeling better and getting better as a business".

When companies identify opportunities for expansion, they develop strategies to push the business towards realistic goals resulting in contributions to eliminate waste, lower costs, reduce the turnover, build a strong brand name, increase the corporate goodwill and maximize value creation to consumers (Godha \& Jain, 2015; Koledoye \& Adeola, 2014). SMEs can increase their chances of survival by developing firm-specific competitive strategies to outperform rivals (Bamiatzi \& Kirchmaier, 2014). The success of a SME owner relies on their ability to react to changes and competition as well as maintaining their relativity and relevance to industry (Ejdys, 2014).

Each participant is a successful SME operating in their respective industry. SME-3 acknowledged the ability to predict strategies towards anticipating movement in the industry. SME-3 noted to be relatable in the industry the recommendation is to "become a member of an owner-operator organization. A bunch of small companies, some even larger companies that are owner operator friendly." SME-3 added, "Through this relationship, with our membership, we 
are kept abreast of the new up and coming rules and regulations. We remain connected to industry and industry standards".

I reviewed SME-3's website during methodological triangulation to validate how they relate to the transportation trucking industry and found that SME-3 was viewed as having one of the lowest driver turnover rates in the industry; with drivers staying with them three times longer than they do competitors. Their professional drivers are among the best on the highways, meeting standards far exceeding those required by the U.S. Department of Transportation. When providing response regarding relate to industry, SME-1 stated, "within the first 5 years, you are getting your name out and you're building your brand, creating your industry niche'." SME-1 added, "Once you start developing your brand and you start developing who you are, then people, and other organizations start to give you the credit or give you the contract or give you the opportunity to make it to the next level." SME-2 stated, "as it pertains to relating to industry to be very strategic and methodical about business practices, especially when it when it comes to the face to face, day to day work." SME-2 continued to say, "you must understand how to move forward and avoid making the mistakes and errors that can potentially cause your downfall. You must know how to navigate in your business with industry".

A key maxim of transformational leadership is organizational and individual goal alignment. SME goal alignment should entail the relation with industry and the familiarity with the operational performance that facilitates being and remaining in business. The alignment of sustainability strategies that participants use to ensure profitability and long-term growth include efficient business establishment planning, commitment to vital customer service, employee satisfaction, community engagement, and regulations compliance (Kim, Kim, \& Qian, 2018). Transformational leadership centers on the assumption that leaders can alter followers' assumptions, behavior, and beliefs by appealing to the importance of the organization's collective outcomes (Veiseh, Mohammadi, Pirzadian, \& Sharafi, 2014). SME-1 and SME-2 acknowledged that transformative leaders remain in a state of transformation and advocate for the ideals and concepts to relate to industry.

The study results indicate that it is prudent for SME owners to ensure their business relates to the industry. More specifically, relating to the industry that the business will be operated within. The participants agreed that to become successful and remain sustainable within the industry you operate within; you must rely on what you know to stay afloat. Participants reinforced Shurbagi (2014) assertion that a transformational leadership style is a central feature of organizational performance and organizational commitment parallels hypothetically and empirically to organizational effectiveness.

Overall, this study revealed SME owners' themes during the operation of their respective business. The three themes considered, shape the successful leadership strategies, and are recommended for SME owners to concert focus for SME 
success. The results also suggest that SME owners are not absolved from considering or applying additional strategies relating to leadership, entrepreneurship, leadership skills, and strategic planning as provided within the literature review. The results indicate that a combined strategic leader focuses on employees, business, and industry, and the application of additional considerations relating to leadership, entrepreneurship, leadership skills, and strategic planning also serve as successful leadership strategies. SME owners in urban areas may use these strategies to sustain their business beyond 5 years.

\section{Applications to Professional Practice}

Effective business leaders rely on the experience and knowledge of subject matter experts, professional colleagues, and consultants to gain the support needed to succeed (Gholston, Kuofie, \& Hakim, 2016). I conducted this multiple qualitative case study to explore leadership strategies that have been successful for SME owners in urban areas to sustain their business beyond 5 years. This study's findings support the conceptual framework of transformational leadership theory as the medium through which SME owners, as leaders, use to sustain and maintain their business beyond 5 years. I found that successful SME owners in urban areas of southeast Georgia used strategies involving employees' focus, maintaining the business, and relating to industry to sustain their business beyond 5 years. The strategies and themes gathered from SME owners may be helpful to future and current SMEs located in other urban areas to avoid operational obstacles, overcome sustainability challenges and adjust from maintainability shortfalls. The themes are ingredients for strategic planning and success, and they align as a focus with the research question and conceptual framework.

Sixty percent of unsuccessful SME's in urban areas fail due to poor management operations and without leadership development for employees (López \& Hiebl, 2015). Although $60 \%$ of small businesses fail within 5 years of startup (SBA, Office of Advocacy, 2016), small businesses create wealth, economic growth, and development in the world (Blankson et al., 2017). SMEs can increase their chances of survival by developing firm-specific competitive strategies to outperform rivals (Bamiatzi \& Kirchmaier, 2014). Andrews (2015) identified that embarking on the sustainability pathway is vital for small businesses in fast-paced business environments. Bamiatzi and Kirchmaier (2014) asserted that business owners who design firm strategies search for profitable products, carefully monitor costs, avoid intense price wars, and witness growth, even in hostile markets.

The findings of this study confirmed researchers' assertion that leadership is an important factor for SME success. Leadership is the capability to motivate employees to use their skills and resources to execute tasks and the practice in which one person affects a group of people to accomplish a mutual goal (Peachey, Zhou, Damon, \& Burton, 2015). Entrepreneurial leadership serves as the guiding ship directing SME owners in the success of respective business ventures 
with ethical leadership filling the moral compass as a foundation for continued business practices. SME owners have contributed immensely to the nurturing of entrepreneurship (Ayandibu \& Houghton, 2017). According to Bartos, Rahman, Horak, and Jacova, (2015), SME owners' entrepreneurial knowledge is a perfect remedy to economic issues. Leadership is relevant to entrepreneurship (Balven et al., 2018). Entrepreneurs must understand SME dynamics and learn to develop appropriate strategies that suit their circumstances to manage SMEs effectively (Bamiatzi \& Kirchmaier, 2014). Entrepreneurs and other small business owners use their networks, experience, and better judgment to obtain collaborative support to identify market risk and capitalize on the rapidly changing technology to benefit their businesses (Kim \& Vonortas, 2014).

Furthermore, the findings may help SME owners grasp the value of transformative leadership. The value of transformative leadership theory is based on the importance of sustainability and authentic leadership (Peterlin, 2016). Leaders and SME owners with comprehensive business plans accomplish business sustainability (Oncioiu, 2014). Sustainability is an institutional commitment reflected throughout the organization's engagement activities and embedded in the governance and decision-making processes (Lee \& Schaltegger, 2014). Small business managers must seek solutions to the challenges they may face to remain sustainable (Summers, 2015). Although viewed as a complex concept according to Aragon-Correa, Marcus, Rivera and Kenworthy (2017) sustainability provides a balance between the economic, social, and environmental goals of an organization (Hansen \& Schaltegger, 2016). Sustainability is referred to something long term (Aragon-Correa et al., 2017) and involves profitability, long-term growth, innovation and creativity, competitive advantage, and every strategy should involve the equilibrium between the three interrelated elements of economy, social, and environment (Krauss, 2017).

\section{Implications for Social Change}

SME owners may use the findings of this study to increase their chance for business success as well as to effect positive social change within the urban communities they thrive. Social change implications include sustained or increased job opportunities, an increase in city, and county tax revenues obtained from sustained employment, a reduction in SME failures and community enhancements provided through improved services and resources. The study's findings through the three themes suggest that successful leadership strategies are beneficial to SMEs and the surrounding communities. The implications for positive social change include the potential for the enhancement of community standards through sustained employment and the leveraging of goods and services financed by increased SMEs sustained presence.

An effective leadership strategy identified in theme 1: Focus on employees. Transformational leaders focus on employee values and goals (Choi, Lim, \& Tan, 2016). Transformational leadership is the main means by which the environ- 
mental changes of the organizations become coordinated (Veiseh et al., 2014). SME owners have contributed immensely to the nurturing of entrepreneurship (Ayandibu \& Houghton, 2017) and SME owners' entrepreneurial knowledge is a perfect remedy to economic issues (Bartos et al., 2015). Improved economic issues are synonymous with having available jobs and increased job opportunities, which spurs spending.

An effective leadership strategy identified in theme 2: Maintain the business. Entrepreneurship facilitates creativity and innovativeness, resulting in business approaches and business decision-making (Haviernikovah, Lemanska-Majdzik, \& Mura, 2017). Through entrepreneurship, businesses grow out of individuals' passion and desire to multiply their profits (Ismail, Husin, Rahim, Kamal, \& Mat, 2016). Small business is an influential source of economic growth and innovation in the United States (Taneja et al., 2016). By way of new job growth, economic support is derived from the small business sector (SBA, 2016). Communities survive and thrive from small business success. Tse and Chiu (2014) confirmed the idea that transformational leadership style is crucial to employee performance and the organization's organizational culture. Cultures where employees share ideas and experience greater inclusion are less likely to express turnover intentions and within cultures that are inclusive, open, and fair, employees feel empowered (Sabharwal, Levine, D’Agostino, \& Nguyen, 2019).

An effective leadership strategy identified in theme 3: Relate to industry.

Business success depends on the decision-making ability and the development and implementation of strategies by business leaders (Myškova \& Doupalova, 2015). Job creation, employee benefits, the supplying of products or services for customers, business-to-business commerce, and tax revenues are the results of successful small businesses (Taneja et al., 2016). Mashahadi, Ahmad, and Mohamad (2016) characterized SMEs with limited human capital (people, knowledge, and capability) as firms with limited resources. Neis et al. (2017) posited that strategic planning is the way small firm owners balance the external environment and their business's internal capabilities. An effective best practice strategy can help business leaders to become more competitive, develop new markets, reduce costs, and become more efficient (Reynolds, 2019). Strategies help small business owners assess how sustainable their businesses are in competitive environments (Chryssochoidis, Dousios, \& Tzokas, 2016). Organizations and their leaders must be more responsive and malleable than ever before, and managers and leaders must act quickly and manage change at a fast pace (Bottomley, Burgess, \& Fox III, 2014).

\section{Recommendations for Action}

SME owners may find the study findings significant and implement strategies and considered themes to sustain their business beyond 5 years. The study results indicated the importance of employees and the impact employees play in the SME owner's success. The study results also indicated the importance of 
maintaining the business as an effective strategy by participants. Study participants identified the importance of having the business be relatable to the industry SME owners operate within, regardless of the product, the service or the medium that either will be delivered. As an effective strategy for SME success in urban areas is imperative to focus on employees. A recurring theme by the participants equally was necessary to "Maintain the Business". The posturing to maintain the business parallels the research by Qureshi, Aziz, and Mian (2017) that entrepreneurship and entrepreneurial perspectives allow the business leaders to be flexible and adapt the best strategies for the unique needs of the business. SMEs are dependent on the environment in which they operate because relationships exist between SMEs and the environments where they exist.

The diversification of the field of entrepreneurship and SMEs reflects the various theoretical perspectives (Rauch, Doorn, \& Hulsink, 2014). Entrepreneurs with entrepreneurship education approach the world with fresh ideas to create desired futures and adopt cognitive acts to reduce uncertainty associated with ambiguous situations (Garbuio, Lovallo, Dong, Lin, \& Tschang, 2018).

The Franchise context of entrepreneurship is expandable to theoretical applications and overlaps. The study of franchising lends itself well to many of the major theories in management, such as agency theory and resource theories. Last, Hyo Jin and Gleiberman employed a franchising lens through which to evaluate our conjectures of CSR. One particularly attractive aspect of franchising from a CSR standpoint again goes back to the mixed results other CSR studies have found.

\section{Recommendations for Further Research}

Gholston et al. (2016) found that SME owners' strategies benefit from the most are creating durable relationships with customers and contemporaries, obtaining the necessary financial and human support, and maintaining the will to succeed and survive in business.

The findings of this study warrant additional exploration of leadership strategies utilized by SME owners in various urban locations. The SME sample size and urban location of southeast Georgia presented limitations to this study. The real-life experiences of SMEs relate to the leadership phenomena; however, the real-life experiences presented have limitations of location and operating time in business. The study was limited to participants in southeast Georgia. Future studies in different locations and more participants may yield additional successful strategies.

Recommendations for further study include the collection of data from SME owners in various urban settings and locations. An additional recommendation is data collection with SME participants within rural locations. Data collection and data analysis performed with other research methodologies and research designs may benefit SME owners and future researchers as well. Key recommendations for SME owners include implementing employee performance training and 
developing strategic planning. The implications for positive social change include the potential for community enhancement opportunities through sustained employment and the leveraging of goods and services financed by SMEs increased and sustained presence.

\section{Conclusion}

Leadership strategies are important to facilitate business success within any small to medium enterprise structure. This qualitative multiple case study was directed to explore successful leadership strategies for SME owners in urban areas to sustain their business beyond 5 years. The conceptual leadership theory of transformational leadership is relevant in SME success in urban areas to overcome those challenges that hinder success. Transformational leaders start by developing a vision, a future view that will excite, motivate, and encourage employees and followers.

The research participant sample consisted of SME owners in urban areas located in southeast Georgia, who have been in business beyond 5 years. SME owners may use the findings of this study to increase their chance for business success as well as effect positive social change in the urban communities they thrive in. Social change implications include sustained or increased job opportunities, an increase in city and county tax revenues obtained from sustained employment, a reduction in SME failures, and community enhancements provided through improved services and resources. The study's findings through the three themes suggest that successful leadership strategies are beneficial to SMEs and the surrounding communities. The themes, focus on employees, maintain the business, and relate to the industry are relevant because of the applicability, relatability, and frequency of occurrence analyzed from participants. The themes are ingredients for strategic planning and success, and the results indicate that the combination of each theme may result in SME success.

\section{Author Information}

Dr. Gregory R. Jackson is a retired US Marine with 22 years of honorable and dedicated service. His study is dedicated to his loving family and friends.

\section{Conflicts of Interest}

The author declares no conflicts of interest regarding the publication of this paper.

\section{References}

Amankwaa, L. (2016). Creating Protocols for Trustworthiness in Qualitative Research. Journal of Cultural Diversity, 23, 121-127. http://www.tuckerpub.com/jcd.htm

Andrews, D. (2015). The Circular Economy, Design Thinking and Education for Sustainability. Local Economy, 30, 305-315. https://doi.org/10.1177/0269094215578226

Aragon-Correa, A. J., Marcus, A. A., Rivera, E. J., \& Kenworthy, A. L. (2017). Sustainabil- 
ity Management Teaching Resources and the Challenge of Balancing Planet, People, and Profits. Academy of Management Learning \& Education, 16, 469-483.

https://doi.org/10.5465/amle.2017.0180

Ayandibu, A. O., \& Houghton, J. (2017). The Role of Small and Medium Scale Enterprise in Local Economic Development (LED). Journal of Business and Retail Management Research, 11, 133-139. http://jbrmr.com/

Balven, R., Fenters, V., Siegel, D. S., \& Waldman, D. (2018). Academic Entrepreneurship: The Roles of Identity, Motivation, Championing, Education, Work-Life Balance, and Organizational Justice. Academy of Management Perspectives, 32, 21-42. https://doi.org/10.5465/amp.2016.0127

Bamiatzi, V. C., \& Kirchmaier, T. (2014). Strategies for Superior Performance under Adverse Conditions: A Focus on Small and Medium-Sized High-Growth Firm. International Small Business Journal, 32, 259-284. https://doi.org/10.1177/0266242612459534

Banker, D. R., Mashruwala, R., \& Tripathy, A. (2014). Does a Differentiation Strategy Lead to More Sustainable Financial Performance than a Cost Leadership Strategy? Management Decision, 52, 872-896. https://doi.org/10.1108/MD-05-2013-0282

Bartos, P., Rahman, A., Horak, J., \& Jacova, H. (2015). Education and Entrepreneurship in the SME Segment in Economic Transformation. Economics \& Sociology, 8, 227-239. https://doi.org/10.14254/2071-789X.2015/8-2/16

Bass, B. M. (1985). Leadership and Performance Beyond Expectations. New York, NY: Free Press.

Bayram, H., \& Dinç, S. (2015). Role of Transformational Leadership on Employee's Job Satisfaction: The Case of Private Universities in Bosnia and Herzegovina. European Researcher, 93, 270-281. https://doi.org/10.13187/er.2015.93.270

Bedarkar, M., \& Pandita, D. (2014). A Study on the Drivers of Employee Engagement Impacting Employee Performance. Procedia-Social and Behavioral Sciences, 133, 106-115. https://doi.org/10.1016/j.sbspro.2014.04.174

Birt, L., Scott, S., Cavers, D., Campbell, C., \& Walter, F. (2016). Member Checking: A Tool to Enhance Trustworthiness or Merely a Nod to Validation? Qualitative Health Research, 26, 1802-1811. https://doi.org/10.1177/1049732316654870

Blankson, C., Cowan, K., \& Darley, W. K. (2017). Marketing Practices of Rural Micro and Small Businesses in Ghana: The Role of Public Policy. Journal of Macromarketing, 38, 29-56. https://doi.org/10.1177/0276146717741067

Bond, G. R., Drake, R. E., McHugo, G. J., Peterson, A. E., Jones, A. M., \& Williams, J. (2014). Long-Term Sustainability of Evidence-Based Practices in Community Mental Agencies. Administration and Policy in Mental Health and Mental Health Services Research, 41, 228-236. https://doi.org/10.1007/s10488-012-0461-5

Bottomley, K., Burgess, S., \& Fox III, M. (2014). Are the Behaviors of Transformational Leaders Impacting Organizations? A Study of Transformational Leadership. International Management Review, 10, 5-9.

http://americanscholarspress.us/journals/IMR/pdf/IMR-1-2014/v10n1-art-1.pdf

Bruyere, B. L. (2015). Giving Direction and Clarity to Conservation Leadership. Conservation Letters, 8, 378-382. https://doi.org/10.1111/conl.12174

Burau, V., \& Andersen, L. B. (2014). Professions and Professionals: Capturing the Changing Role of Expertise through Theoretical Triangulation. American Journal of Economics \& Sociology, 73, 264-293. https://doi.org/10.1111/ajes.12062

Burns, J. M. (1978). Leadership. New York, NY: Harper \& Row.

Campbell, J., \& Goritz, A. (2014). Culture Corrupts! A Qualitative Study of Organization- 
al Culture in Corrupt Organizations. Journal of Business Ethics, 120, 291-311. https://doi.org/10.1007/s10551-013-1665-7

Campbell, J., Im, T., \& Jisu, J. (2014). Internal Efficiency and Turnover Intention: Evidence from Local Government in South Korea. Public Personnel Management, 43, 259-282. https://doi.org/10.1177/0091026014524540

Carter, N., Bryant-Lukosius, D., DiCenso, A., Blythe, J., \& Neville, A. J. (2014). The Use of Triangulation in Qualitative Research. Oncology Nursing Forum, 41, 545-547. https://doi.org/10.1188/14.ONF.545-547

Chang, W. L., Liu, W. G. H., \& Chiang, S. M. (2014). A Study of the Relationship between Entrepreneurship Courses and Opportunity Identification: An Empirical Survey. Asia Pacific Management Review, 19, 1-24.

Choi, S. B., Tran, T. B. H., \& Park, B. I. (2015). Inclusive Leadership and Work Engagement: Mediating Roles of Affective Organizational Commitment and Creativity. Social Behavior \& Personality: An International Journal, 43, 931-943. https://doi.org/10.2224/sbp.2015.43.6.931

Choi, S. L., Lim, Z. Y., \& Tan, W. C. (2016). Analysis of the Relationship between Leadership Styles and Affective Organizational Commitment. International Journal of Management, Accounting \& Economics, 3, 572-598. http://www.ijmae.com/

Chryssochoidis, G., Dousios, D., \& Tzokas, N. (2016). Small Firm Adaptive Capability, Competitive Strategy, and Performance Outcomes: Competing Mediation vs. Moderation Perspectives. Strategic Change, 25, 441-466. https://doi.org/10.1002/jsc.2073

Dalpiaz, E., Tracey, P., \& Phillips, N. (2017). Succession Narratives in Family Business: The Case of Alessi. Entrepreneurship: Theory and Practice, 38, 1375-1394.

Dasgupta, M. (2015). Exploring the Relevance of Case Study Research. Vision: The Journal of Business Perspective, 19, 147-160. https://doi.org/10.1177/0972262915575661

David, M., \& Rowe, F. (2016). What Does PLMS (Product Lifecycle Management Systems) Manage: Data or Documents? Complementarity and Contingency for SMEs. Computers in Industry, 75, 140-150. https://doi.org/10.1016/j.compind.2015.05.005

De Massis, A., \& Kotlar, J. (2014). The Case Study Method in Family Business Research: Guidelines for Qualitative Scholarship. Journal of Family Business Strategy, 5, 15-29. https://doi.org/10.1016/j.jfbs.2014.01.007

Dowling, M., Brown, P., Legg, D., \& Beacom, A. (2018). Review: Living with Imperfect Comparisons: The Challenges and Limitations of Comparative Paralympic Sport Policy Research. Sport Management Review, 21, 101-113. https://doi.org/10.1016/j.smr.2017.05.002

Duan, N., Bhaumik, D. K., Palinkas, L. A., \& Hoagwood, K. (2015). Optimal Design and Purposeful Sampling: Complementary Methodologies for Implementation Research. Administration and Policy in Mental Health and Mental Health Services Research, 42, 524-532. https://doi.org/10.1007/s10488-014-0596-7

Ejdys, J. (2014). Strategic Orientation of Small and Medium-Size Enterprises. Economics \& Management, 19, 346-358.

Elo, S., Kääriäinen, M., Kanste, O., Pölkki, T., Utriainen, K., \& Kyngäs, H. (2014). Qualitative Content Analysis: A Focus on Trustworthiness. SAGE Open, 4. https://doi.org/10.1177/2158244014522633

Frieder, R. E., Wang, G., \& Oh, I. S. (2018). Linking Job-Relevant Personality Traits, Transformational Leadership, and Job Performance via Perceived Meaningfulness at Work: A Moderated Mediation Model. Journal of Applied Psychology, 103, 324-333. https://doi.org/10.1037/apl0000274 
Fusch, P. I., Fusch, G. E., \& Ness, L. R. (2017). How to Conduct a Mini-Ethnographic Case Study: A Guide for Novice Researchers. The Qualitative Report, 22, 923-941. http://questia.com

Galdas, P. (2017). Revisiting Bias in Qualitative Research: Reflections on Its Relationship with Funding and Impact. International Journal of Qualitative Methods, 16, 1-2. https://doi.org/10.1177/1609406917748992

Garbuio, M., Lovallo, D., Dong, A., Lin, N., \& Tschang, T. (2018). Demystifying the Genius of Entrepreneurship: How Design Cognition Can Help Create the Next Generation of Entrepreneurs. Academy of Management Learning \& Education, 17, 41-61. https://doi.org/10.5465/amle.2016.0040

Gelling, L. (2015). Stages in the Research Process. Nursing Standard, 29, 44-49. https://doi.org/10.7748/ns.29.27.44.e8745

Gholston, K., Kuofie, M., \& Hakim, A. C. (2016). Social Media for Marketing by Small Businesses. Journal of Marketing Management, 7, 24-39. https://www.tandfonline.com/loi/rjmm20

Godha, A., \& Jain, P. (2015). Sustainability Reporting Trend in Indian Companies as per GRI Framework: A Comparative Study. South Asian Journal of Business and Management Cases, 4, 62-73. https://doi.org/10.1177/2277977915574040

Gottfert, E. (2015). Embedding Case Study Research into the RESEARCH context. International Journal of Sales, Retailing \& Marketing, 4, 23-32. http://ijsm.com

Graue, C. (2015). Qualitative Data Analysis. International Journal of Sales, Retailing and Marketing, 4, 5-14. www.scirp.org/reference/referencespapers.aspx

Groth, O. J., Esposito, M., \& Tse, T. (2015). What Europe Needs Is an Innovation-Driven Entrepreneurship Ecosystem: Introducing EDIE. Thunderbird International Business Review, 57, 263-269. https://doi.org/10.1002/tie.21709

Hansen, E. G., \& Schaltegger, S. (2016). The Sustainability Balanced Scorecard: A Systematic Review of Architectures. Journal of Business Ethics, 133, 193-221. https://doi.org/10.1007/s10551-014-2340-3

Haviernikovah, K., Lemanska-Majdzik, A., \& Mura, L. (2017). Advantages and Disadvantages of the Participation of SMEs in Tourism Clusters. Journal of Environmental Management and Tourism, 6, 1205-1215.

Houghton, C., Casey, D., Shaw, D., \& Murphy, K. (2013). Rigour in Qualitative Case Study Research. Nurse Researcher, 20, 12-17.

Hulbert, B., Gilmore, A., \& Carson, D. (2015). Opportunity Recognition by Growing SMEs: A Managerial or Entrepreneurial Function? Journal of Strategic Marketing, 23, 616-642. https://doi.org/10.1080/0965254X.2014.1001868

Hundera, M. B. (2014). Micro and Small-Scale Enterprises (MSEs) Development Services in Women's Entrepreneurial Start-Ups in Ethiopia: A Study Conducted in Three Cities: Dire Dawa, Harar and Jigjiga. Journal of Behavioral Economics, Finance, Entrepreneurial, Accounting and Transport, 2, 77-88.

Ismail, I., Husin, N., Rahim, N. A., Kamal, M. H. M., \& Mat, R. C. (2016). Entrepreneurial Success among Single Mothers: The Role of Motivation and Passion. Procedia Economics and Finance, 37, 121-128. https://doi.org/10.1016/S2212-5671(16)30102-2

Jackson, K., Paulus, T., \& Woolf, N. H. (2018). The Walking Dead Genealogy: Unsubstantiated Criticisms of Qualitative Data Analysis Software (QDAS) and the Failure to Put Them to Rest. The Qualitative Report, 23, 74-91.

https://nsuworks.nova.edu/cgi/viewcontent.cgi?article=3096\&context=tqr 
Jayawarna, D., Jones, O., \& Macpherson, A. (2014). Entrepreneurial Potential: The Role of Human and Cultural Capitals. International Small Business Journal, 32, 918-943. https://doi.org/10.1177/0266242614525795

Jeger, M., Sarlija, N., \& Bilandzic, A. (2016). Financial Determinants of SMEs Growth in the Time of Economic Downturn. Review of Contemporary Business, Entrepreneurship, and Economic Issues, 29, 335-345. http://hrcak.srce.hr

Kim, K.-H., Kim, M. C., \& Qian, C. (2018). Effects of Corporate Social Responsibility on Corporate Financial Performance: A Competitive-Action Perspective. Journal of Management, 44, 1097-1118. https://doi.org/10.1177/0149206315602530

Kim, Y., \& Vonortas, N. S. (2014). Cooperation in the Formative Years: Evidence from Small Enterprises in Europe. European Management Journal, 32, 795-805. https://doi.org/10.1016/j.emj.2014.02.003

Koledoye, R., \& Adeola, O. O. (2014). Economic Success of Credit Department Micro-Enterprises in Oyo State. International Business Management, 8, 93-96.

Kornberger, M. (2017). The Values of Strategy: Valuation Practices, Rivalry and Strategic Agency. Organization Studies, 38, 1753-1773. https://doi.org/10.1177/0170840616685365

Krauss, J. (2017). What Is Cocoa Sustainability? Mapping Stakeholders' Socio-Economic, Environmental, and Commercial Constellations of Priorities. Enterprise Development and Microfinance, 28, 228-250. https://doi.org/10.3362/1755-1986.17-000JK

Lee, K., \& Schaltegger, S. (2014). Organizational Transformation and Higher Sustainability Management Education. International Journal of Sustainability in Higher Education, 15, 450-472. https://doi.org/10.1108/IJSHE-06-2013-0067

Leung, L. (2015). Validity, Reliability, and Generalizability in Qualitative Research. Journal of Family Medicine and Primary Care, 4, 324-327.

Lewis, S. (2015). Qualitative Inquiry and Research Design: Choosing among Five Approaches. Health Promotion Practice, 16, 473-475. https://doi.org/10.1177/1524839915580941

Lin, Y. C., Yu, C., \& Yi, C. C. (2014). The Effects of Positive Affect, Person-Job Fit, and Well-Being on Job Performance. Social Behavior Personality, 42, 1537-1547. https://doi.org/10.2224/sbp.2014.42.9.1537

Lofti, N., Nayebzadeh, S., \& Debnavi, H. D. (2014). Factors Affecting Growth and Development on SMEs (Case Study: Ardebil City). Journal of Applied Environmental and Biological Sciences, 4, 139-146. http://www.textroad.com/

López, O. L., \& Hiebl, M. W. (2015). Management Accounting in Small and Medium-Sized Enterprises: Current Knowledge and Avenues for Further Research. Journal of Management Accounting Research, 27, 81-119.

https://doi.org/10.2308/jmar-50915

Marshall, C., \& Rossman, G. B. (2016). Designing Qualitative Research (6th ed.). Thousand Oaks, CA: Sage.

Mashahadi, F., Ahmad, N. H., \& Mohamad, O. (2016). Strategic Innovation Ambidexterity and the Internationalization Performance of Small and Medium Enterprises. World Journal of Entrepreneurship, Management and Sustainable Development, 12, 161-175. https://doi.org/10.1108/WJEMSD-09-2015-0036

McDowell, W. C., Gibson, S. G., Aaron, J., Harris, M. L., \& Lester, D. L. (2014). Analyzing the Link between Strategy and Performance: Comparing Small Business Owners and Professional Managers. Journal of Business \& Entrepreneurship, 26, 45-65. 
https://www2.stetson.edu/asbe/wp-content/uploads/2017/06/ASBE-Proceedings-of-the -2014-Program.pdf\#page $=30$

Merriam, S. B. (2014). Qualitative Research: A Guide to Design and Implementation. San Francisco, CA: Jossey-Bass.

Miles, M. B., Huberman, A. M., \& Saldaña, J. (2014). Qualitative Data Analysis: A Methods Sourcebook (3rd ed.). Thousand Oaks, CA: Sage.

Mom, T. J. M., van Neerijnen, P. V., Reinmoeller, P., \& Verwaal, E. (2015). Relational Capital and Individual Exploration: Unraveling the Influence of Goal Alignment and Knowledge Acquisition. Organizational Studies, 36, 809-829.

https://doi.org/10.1177/0170840615580009

Morgado, F. F. R., Meireles, J. F. F., Neves, C. M., Amaral, A. C. S., \& Ferreira, M. E. C. (2018). Scale Development: Ten Main Limitations and Recommendations to Improve Future Research Practices. Psicologia: Reflexão e Crítica, 30, Article No. 3. https://doi.org/10.1186/s41155-016-0057-1

Morrison, C. C., Greenshaw, L. L., \& Pigg, J. (2019). Is It Worth It? A Case Study Exploring Volunteers' Perceptions of Leadership Training. Journal of Leadership Education, $18,81-92$.

Morse, J. M. (2015a). “Data Were Saturated...”. Qualitative Health Research, 25, 587-588. https://doi.org/10.1177/1049732315576699

Morse, J. M. (2015b). Critical Analysis of Strategies for Determining Rigor in Qualitative Inquiry. Qualitative Health Research, 25, 1212-1222. https://doi.org/10.1177/1049732315588501

Moser, A., \& Korstjens, I. (2018). Series: Practical Guidance to Qualitative Research. Part 3: Sampling, Data Collection and Analysis. European Journal of General Practice, 24, 9-18. https://doi.org/10.1080/13814788.2017.1375091

Mustafa, R. (2015). Business Model Innovation: Pervasiveness of Mobile Banking Ecosystem and Activity System-An Illustrative Case of Telenor Easypaisa. Journal of Strategy and Management, 8, 342-367. https://doi.org/10.1108/JSMA-06-2014-0054

Myškova, R., \& Doupalova, V. (2015). Approach to Risk Management Decision-Making in the Small Business. Procedia Economics and Finance, 34, 329-336.

https://doi.org/10.1016/S2212-5671(15)01637-8

Neagu, C. (2016). The Importance and Role of Small and Medium-Sized Businesses. Theoretical \& Applied Economics, 331-338. http://www.ectap.ro/

Neis, D. F., Pereira, M. F., \& Maccari, A. E. (2017). Strategic Planning Process and Organizational Structure: Impacts, Confluence, and Similarities. Brazilian Business Review, 14, 479-492. https://doi.org/10.15728/bbr.2017.14.5.2

Northouse, P. G. (2015). Leadership: Theory and Practice. Thousand Oaks, CA: Sage.

Oncioiu, I. (2014). Risk Prevention Strategies and the SWOT Analysis for the Implementation of the SME's Business Plan. Acta Universitatis Danubius: Oeconomica, 10, 160-170. http://journals.univ-danubius.ro/index.php/oeconomica

Pardo-del-Val, M., Fuentes, C., \& Dobón, S. (2012). Participative Management and Its Influence on Organizational Change. Management Decision, 50, 1843-1860. https://doi.org/10.1108/00251741211279639

Pattinson, S. (2016). Strategic Thinking: Intelligent Opportunism and Emergent Strategy-The Case of Strategic Engineering Services. Entrepreneurship and Innovation, 17, 65-70. https://doi.org/10.5367/ijei.2015.0212

Peachey, J., Zhou, Y., Damon, Z., \& Burton, L. (2015). Forty Years of Leadership Research 
in Sports Management: A Review, Synthesis and Conceptual Framework. Journal of Sport Management, 29, 570-587. https://doi.org/10.1123/jsm.2014-0126

Peterlin, J. (2016). Incorporation of Sustainability into Leadership Development. Economic and Business Review, 18, 31.

Ployhart, R. E., Nyberg, A. J., Reilly, G., \& Maltarich, M. A. (2014). Human Capital Is Dead; Long Live Human Capital Resources! Journal of Management, 40, 371-398. https://doi.org/10.1177/0149206313512152

Pontikes, E. G., \& Barnett, W. P. (2017). The Non-Consensus Entrepreneur: Organizational Responses to Vital Events. Administrative Science Quarterly, 62, 140-178. https://doi.org/10.1177/0001839216661150

Pooe, D., Mafini, C., \& Loury-Okoumba, V. (2015). The Influence of Information Sharing Supplier Trust and Supplier Synergy on Supplier Performance: The Case of Small and Medium Enterprises. Journal of Transport and Supply Chain Management, 9, a187. https://doi.org/10.4102/jtscm.v9i1.187

Popa, D., \& Miricescu, D. (2015). Identification of Strategic Actions and Types of Strategies Adopted in SMEs from Sibiu County. Review of Management \& Economic Engineering, 14, 279-296.

https://web.a.ebscohost.com/abstract?direct=true\&profile=ehost\&scope=site\&authtype $=$ crawler\&jrnl=1583624X\&AN=108357243\&h=\%2ffMLIHRemxaluldI1KPJVHXNqqoo cXvaytcz0mlkqIdR9Vw55hDNIQBrxigGiTQKo1zcnnzNxJV5EP9On2FHPw\%3d\%3d\& $\underline{\mathrm{crl}=\mathrm{c} \& \text { resultNs=AdminWebAuth\&resultLocal=ErrCrlNotAuth\&crlhashurl=login.aspx }}$ \%3fdirect\%3dtrue\%26profile\%3dehost\%26scope\%3dsite\%26authtype\%3dcrawler\%26jr nl\%3d1583624X\%26AN\%3d108357243

Posner, B. Z. (2016). Investigating the Reliability and Validity of the Leadership Practices Inventory. Administrative Sciences, 6, 17. https://doi.org/10.3390/admsci6040017

Pradhan, S., \& Pradhan, R. K. (2015). An Empirical Investigation of Relationship among Transformational Leadership, Affective Organizational Commitment and Contextual Performance. Vision: The Journal of Business Perspective, 19, 227-235. https://doi.org/10.1177/0972262915597089

Prince, M., Burns, D., Lu, X., \& Winsor, R. (2015). Knowledge and Skills Transfer between MBA and Workplace. Journal of Workplace Learning, 27, 207-225.

https://doi.org/10.1108/JWL-06-2014-0047

Qureshi, M. S., Aziz, N., \& Mian, S. A. (2017). How Marketing Capabilities Shape Entrepreneurial Firm's Performance? Evidence from New Technology-Based Firms in Turkey. Journal of Global Entrepreneurship Research, 7, Article No. 15. https://doi.org/10.1186/s40497-017-0071-5

Rauch, A., Doorn, R. V., \& Hulsink, W. H. (2014). A Qualitative Approach to Evidence-Based Entrepreneurship: Theoretical Considerations and an Example Involving Business Clusters. Entrepreneurship: Theory \& Practice, 38, 333-368.

https://doi.org/10.1111/etap.12093

Ravitch, S., \& Carl, N. M. (2016). Qualitative Research: Bridging the Conceptual, Theoretical, and Methodological. Thousand Oaks, CA: Sage Publications.

Reynolds, B. G. (2019). What Do People Want from Work? The Simple Question That Can Transform Unit Engagement and Retention. Air and Space Power Journal, 33, 4. https://www.airuniversity.af.edu/ASPJ/

Ridder, H. (2017). The Theory Contribution of Case Study Research Designs. Business Research, 10, 281-305. https://doi.org/10.1007/s40685-017-0045-Z

Sabharwal, M., Levine, H., D’Agostino, M., \& Nguyen, T. (2019). Inclusive Work Practic- 
es: Turnover Intentions among LGBT Employees of the U.S. Federal Government. American Review of Public Administration, 49, 482-494. https://doi.org/10.1177/0275074018817376

Sahin, D., Cubuk, D., \& Uslu, T. (2014). The Effect of Organizational Support, Transformational Leadership, Personnel Empowerment, Work Engagement, Performance and Demographical Variables on the Factors of Psychological Capital. Emerging Markets Journal, 3, 1-17. https://doi.org/10.5195/EMAJ.2014.49

Sahut, J., \& Peris-Ortiz, M. (2014). Small Business, Innovation, and Entrepreneurship. Small Business Economics, 42, 663-668. https://doi.org/10.1007/s11187-013-9521-9

Seidman, I. (2015). Interviewing as Qualitative Research: A Guide for Researchers in Education and the Social Sciences (4th ed.). New York, NY: Teachers College Press.

Shayestefar, M., \& Abedi, H. (2017). Leading Factors to Surrogacy from Pregnant Surrogate Mothers' Vantage Point: A Qualitative Research. International Journal of Women's Health and Reproduction Sciences, 5, 97-102.

https://doi.org/10.15296/ijwhr.2017.18

Shurbagi, A. M. A. (2014). The Relationship between Transformational Leadership Style, Job Satisfaction and the Effect of Organizational Commitment. International Business Research, 7, 126-139. https://doi.org/10.5539/ibr.v7n11p126

Stanton, N. A. (2016). On the Reliability and Validity of, and Training in, Ergonomics Methods: A Challenge Revisited. Theoretical Issues in Ergonomics Science, 17, 345-353. https://doi.org/10.1080/1463922X.2015.1117688

Summers, D. (2015). The Economic Impact of Entrepreneurship: Setting Realistic Expectations. Academy of Entrepreneurship Journal, 21, 99-107.

https://search.proquest.com/openview/9aece2114e79e8f88ee70aa782904c7e/1?pq-origsi te $=$ gscholar\&cbl=29726

Taneja, S., Pryor, M. G., \& Hayek, M. (2016). Leaping Innovation Barriers to Small Business Longevity. Journal of Business Strategy, 37, 44-51.

https://doi.org/10.1108/JBS-12-2014-0145

Tse, H. M., \& Chiu, W. C. (2014). Transformational Leadership and Job Performance: A Social Identity Perspectives. Journal of Business Research, 67, 2827-2835.

https://doi.org/10.1016/j.jbusres.2012.07.018

U.S. Small Business Administration (2016). Office of Advocacy: United States Small Business Profile. https://www.sba.gov/sites/default/files/advocacy/United_States.pdf

U.S. Small Business Administration (SBA), Office of Advocacy (2016). Frequently Asked Questions. https://www.sba.gov/advocacy/small-business-advocate-jaunary-2016

U.S. Small Business Administration (SBA), Office of Advocacy (2017). Frequently Asked Questions about Small Business.

http://www.sba.gov/sites/default/files/advocacy/SB-FAQ-2017-WEB.pdf

U.S. Small Business Administration (SBA), Office of Advocacy (2018). 2018 Small Business Profile-GA. https://www.sba.gov/sites/default/files/advocacy/2018-Small-Business-Profiles-GA.pdf

Valentin, C. (2014). The Extra Mile Deconstructed: A Critical and Discourse Perspective on Employee Engagement and HRD. Human Resource Development International, 17, 475-490. https://doi.org/10.1080/13678868.2014.932091

Veiseh, S., Mohammadi, E., Pirzadian, M., \& Sharafi, V. (2014). The Relation between Transformational Leadership and Organizational Culture (Case Study: Medical School of Ilam). Journal of Business Studies Quarterly, 5, 113-124.

http://citeseerx.ist.psu.edu/viewdoc/download?doi=10.1.1.652.8229\&rep=rep1\&type=pdf 
Wallace, M., \& Sheldon, N. (2015). Business Research Ethics: Participant Observer Perspectives. Journal of Business Ethics, 128, 267-277.

https://doi.org/10.1007/s10551-014-2102-2

Wang, X. H., Hawkins, C., \& Berman, E. (2014). Financing Sustainability and Stakeholder Engagement: Evidence from U.S. Cities. Urban Affairs Review, 50, 806-834. https://doi.org/10.1177/1078087414522388

Weber, P., Geneste, L. A., \& Connell, J. (2015). Small Business Growth: Strategic Goals and Owner Preparedness. The Journal of Business Strategy, 36, 30-36. https://doi.org/10.1108/JBS-03-2014-0036

Williams, T. L., \& Needham, C. R. (2016). Transformation of a City: Gentrification's Influence on the Small Business Owners of Harlem, New York. SAGE Open, 6. https://doi.org/10.1177/2158244016673631

Wilson, V. (2014). Research Methods: Triangulation. Evidence Based Library and Information Practice, 9, 74-75. https://doi.org/10.18438/B8WW3X

Yin, R. K. (2018). Case Study Research and Applications: Design and Methods (6th ed.). Thousand Oaks, CA: Sage. 